\title{
KAJIAN ASPEK EKONOMI PENGELOLAAN HASIL HUTAN DI HULU DAS WAE RIUPA KABUPATEN SERAM BAGIAN BARAT
}

\author{
STUDY OF ECONOMIC ASPECTS OF FOREST PRODUCT MANAGEMENT IN THE \\ UPSTREAM WAE RIUPA WATERSHED, WEST SERAM DISTRICT \\ oleh \\ Rosita M. Elly ${ }^{1}$; Gun Mardiatmoko² ${ }^{2}$ Debby Vemiancy Pattimahu ${ }^{2}$ \\ ${ }^{1}$ Mahasiswa Prodi Manajemen Hutan Program Pascasarjana Universitas Pattimura, Ambon \\ ${ }^{2,3}$ Prodi Manajemen Hutan Program Pascasarjana Universitas Pattimura, Ambon, 97233 \\ Email : rosita.elly@gmail.com

\begin{tabular}{|l|l} 
Diterima: 8 Agustus 2020 & Disetujui: 20 September 2020
\end{tabular}

\begin{abstract}
Abstrak
Penilaian hutan untuk mengkuantifikasi Nilai Ekonomi Total elah banyak dilakukan di berbagai negara. Perkembangan penilaian hutan, selain hasil hutan yang memiliki pasar (market goods), juga telah berkembang metode perhitungan nilai ekonomi hasil hutan yang tidak dapat ditentukan dengan sistem pasar (non market good). Penelitian ini bertujuan untuk untuk mengkaji aspek ekonomi pengelolaan hasil hutan di Hulu DAS Wae Riupa Kabupaten Seram Bagian Barat. Hasil penelitian menunjukkan bahwa Hasil perhitungan nilai penggunaan langsung (Direct Use Value), nilai penggunaan tidak langsung (indirect use value) sebesar Rp. 1.645.920.00,-, nilai pilihan (option value) sebesar Rp. 458.642.449,-, manfaat pilihan sebesar Rp. 11.384.651.002, dan nilai ekonomi total (Total Economy Value - TEV) sebesar 13.489.213.451,-. Potensi hasil hutan yang dimanfaatkan dan dikelola oleh masyarakat di Desa Rambatu sebagian besar berasal dari hutan, meliputi hasil hutan kayu, aneka-ragam satwa yang kaya, hasil hutan bukan kayu dan jasa lingkungan.
\end{abstract}

Kata kunci : nilai ekonomi, hasil hutan, Hulu DAS Riupa

\begin{abstract}
Forest assessments to quantify Total Economic Value have been carried out in many countries. The development of forest valuation, apart from forest products that have a market goods. Nowdys various methods of calculating forest product economic value that cannot be determined by the market system (non market goods) have developed. This study examined the economic aspects of forest product management in the upper watershed of Wae Riupa, West Seram Regency. The results showed of calculating the value of direct use Direct use Value, the value of indirect use (indirect use-value) of Rp. 1. 645,920.00, -, the option value is Rp. 458.642,449, -, optional benefits of Rp. 11. 384,651,002, and the total economic value (TEV) of $13.489,213,451$, -. Most of the potential forest products used and managed by the community in Rambatu Village come from forests, including timber forest products, various kinds of rich animals, non-timber forest products, and environmental services.
\end{abstract}

Keywords: economic value, forest products, Upstream Riupa Watershed 


\section{PENDAHULUAN}

Pengelolaan hutan lestari merupakan proses pengelolaan lahan hutan tetap untuk mencapai satu atau lebih tujuan mengenai produksi hasil dan jasa hutan tanpa mengurangi nilai-nilai inherent dan produktivitas masa depan serta tidak menimbulkan dampak lingkungan baik lingkungan fisik maupun sosial (Bahruni dkk, 2007). Pengelolaan hutan lestari dapat tercapai apabila persoalan ekologi, ekonomi dan sosial menjadi satu kesatuan yang tak terpisahkan, yang menggaambarkan adanya hubungan interdependensi antar semua aspek yang terkait. Persoalan ekologis lebih menitikberatkan pada hubungan menjaga status dan fungsi ekosistem alam, sedangkan persoalan ekonomi adalah bagaimana memelihara dan meningkatkan standar kehidupan manusia. Persoalan sosial adalah bagaimana memelihara proses sosial manusia yang menjamin keterpeliharaan peluang dan kesempatan yang adil di masa datang, tidak terjadi eksploitasi, penindasan, kekerasan, serta pengalihan beban yang berlebihan (Fakultas Kehutanan IPB, 1999).

Sumberdaya hutan menghasilkan berbagai manfaat yang diperoleh masyarakat yang meliputi manfaat yang nyata dapat diukur (tangible) berupa hasil hutan kayu, hasil hutan bukan kayu seperti damar, rotan, satwa buruan, buah-buahan, sayuran, tumbuhan obat-obatan, maupun manfaat yang tidak dapat diukur (intangible) berupa manfaat perlindungan lindungan lingkungan, keragaman genetic dan lain-lain (Jefri, 2014). Berbagai manfaat sumberdaya hutan dapat dinilai secara rendah sehingga menimbulkan eksploitasi sumberdaya hutan secara berlebihan. Hal ini disebabkan karena masih banyak pihak yang belum memahami nilai dari berbagai manfaat sumberdaya hutan secara holistik dan komprehensif. Untuk memahami manfaat dari sumberdaya hutan perlu dilakukan penlaian terhadap semua manfaat yang dihasilkan sumberdaya hutan. Penilaian sendiri merupakan upaya untuk menentukan nilai atau manfaat dari suatu barang atau jasa untuk kepentingan manusia. Dengan diketahuinya manfaat SDH, maka strategi pengelolaan hasil hutan dari suatu wilayah dapat direkomendasikan kepada para pengambil kebijakan untuk mengalokasikan sumberdaya alam (SDA) yang semakin langka dan melakukan distribusi manfaat SDA yang adil dan bekelanjutan (Hakim, 2009).

Manfaat sumberdaya hutan sendiri tidak semuanya memiliki nilai harga pasar, sehingga perlu digunakan pendekatanpendekatan untuk mengkuantifikasi nilai ekonomi sumberdaya hutan dalam satuan moneter. Sebagai contoh manfaat hutan dalam menyerap karbon dan manfaat ekologis lingkungan lainya. Sifatnya yang non-market inilah menyebabkan banyak manfaat sumberdaya hutan belum dinilai secara memuaskan dalam perhitungan ekonomi. Kepedulian akan pentingnya manfaat lingkungan semakin meningkatk dengan melihat kondisi sumberdaya alam yang semakin terdegradasi (Hasibuan, 2014).

Penilaian hutan untuk mengkuantifikasi nilai ekonomi total (NET) telah bnayak dilakukan di berbagai negara. Perkembangan penilaian hutan, selain hasil hutan yang memiliki pasar (market goods), sekarang ini telah berkembang berbagai metode perhitungan nilai ekonomi hasil hutan yang tidak dapat ditentukan dengan sistem pasar (non market good). Hasil penelitian NET telah banyak dilakukan penelitian dalam negeri maupun luar negeri antara lain : Rakhal dan Surry (1998), Bishop (1999), Fakultas Kehutanan IPB (1999), Bahruni dkk, (2002), Widada (2004) yang 
menggambarkan NET pada kondisi hutan tertentu. Sejumlah inf ormasi NET hutan menjelaskan kondisi hutan yang dinilai, belum dapat menggambarkan perubahan NET jika kondisi ekosistem berubah.

\section{METODE PENELITIAN}

Penelitian ini akan di laksanakan pada Hulu DAS Wae Riupa Kabupaten Seram Bagian Barat. Objek penelitian adalah masyarakat di sekitar hulu DAS Wae Riuapa Desa Rambatu Kecamatan Inamosol sedangkan Responden adalah Staholder dan masyarakat sekitar hulu DAS Wae Riuapa Desa Rambatu Kecamatan Inamosol. Waktu Penelitian dilaksanakan pada bulan Agustus 2018 sampai dengan Januari 2019. Alat dan bahan yang digunakan dalam penelitian ini meliputi daftar kuisioner, papan oles, alat tulis menulis, kamera, peta lokasi penelitian, penggrais (mistar), dan seperangkat komputer dan program pengolahan data ekonomi. Metode yang digunakan dalam penelitian ini adalah metode deskriptif dengan teknik observasi dan wawancara.

\section{HASIL DAN PEMBAHASAN}

Penilaian sumberdaya hutan secara ekonomi adalah penentuan nilai manfaat suatu barang ataupun jasa bagi masyarakat. Adanya nilai yang dimiliki oleh suatu barang dan jasa (sumberdaya dan lingkungan) pada gilirannya akan mengarahkan perilaku pengambilan keputusan yang dilakukan oleh individu, masyarakat maupun organisasi. Nilai sumberdaya (ekosistem) hutan, ataupun lebih spesifik barang dan jasa hutan telah tersedia informasinya, seperti halnya harga berbagai produk yang ada di pasar, maka pengelolaan hutan dapat memanfaatkannya untuk berbagai keperluan seperti pengambilan keputusan pengelolaan, perencanaan dan lain-lain (Bahruni dkk,
Berdasarkan uraian di atas, maka penelitian bertujuan untuk mengkaji aspek ekonomi pengelolaan hasil hutan di Hulu DAS Wae Riupa Kabupaten Seram Bagian Barat.

Metode observasi terkait pengukuran data lapangan, dan metode wawancara terkait pengelolaan hutan yang dilakukan oleh masyarakat Desa Rambatu.

Analisis estimasi nilai ekonomi dari hutan produksi secara kuantitatif dengan menggunkan rumus sebagai berikut:

$$
\begin{aligned}
& \text { TEV = DUV+IUV+O+BV+EV } \\
& \text { Dimana: TEV = Total Economic } \\
& \text { Value (Nilai Ekonomi Total) } \\
& \text { DUV = Use Value ( nilai } \\
& \text { manfaat langsung) } \mathrm{IUV}=\text { Indirect } \\
& \text { Use Value (Nilai manfaat tidak langsung) } \\
& \text { OV = Option Value } \\
& \text { (nilai pilihan) } \quad \mathrm{BV}=\text { Bequest Value } \\
& \text { (nilai Warisan) } \quad \mathrm{EV}=\text { Existensi } \\
& \text { Value (nilai eksistensi) }
\end{aligned}
$$

2007). Tidak tersedianya informasi nilai (harga) dari produk/ jasa hutan maka diperlukan suatu usaha kreatif untuk menduga nilai sumberdaya hutan. Belum tersedianya informasi nilai (harga) dari hutan disebabkan karena produk barang/jasa hutan tidak seragam atau tidak standar karena merupakan hasil alam, sehingga sulit dibuat harga standar yang berlaku umum. Oleh karena itu diperlukan suatu usaha untuk menduga nilai dari sumberdaya hutan.

Penilaian ekonomi merupakan suatu peralatan ekonomi yang menggunakan teknik penilaian sumberdaya untuk mengestimasi nilai uang dari barang dan jasa yang diberikan oleh suatu kawasan (Siti Latifah, 2004). Penilaian hutan bukan berusaha untuk 
mengadakan nilai yang tidak ada, tetapi suatu upaya bagaimana memunculkan nilai-nilai sesungguhnya yang dimiliki oleh hutan, yang secara nyata dirasakan manfaatnya oleh individu atau masyarakat, yang oleh berbagai sebab besar nilai tesebut belum diketahui.

Sebagai salah satu sumberdaya alam yang dapat dimanfaatkan untuk memenuhi kebutuhan manusia, manfaat hutan dapat dibedakan menjadi dua, yaitu : manfaat tangible (langsung/nyata) dan manfaat intangible (tidak langsung atau tidak nyata). Manfaat tangible atau manfaat langsung hutan antara lain : pengaturan tata air, rekreasi, pendidikan, kenyamanan lingkungan, dan lain-lain (Affandi dan Patina, 2004). Manfaat tangible diantaranya

\section{Nilai Penggunaan Langsung (Direct Use Value)}

Nilai penggunaan langsung merupakan nilai yang didapatkan oleh masyarakat akibat interaksi langsung terhadap suatu sumberdaya alam guna pemenuhan akan kebutuhan dan juga sebagai mata pencarian. Berdasarkan hasil identifikasi secara garis besar nilai penggunaan langsung yang didapatkan oleh masyarakat Desa Rambatu Kecamatan berupa hasil kayu dan non kayu. Hasil hutan kayu dimanfaatkan untuk keperluan kayu perkakas dan kayu bakar. Sedangkan hasilhasil hutan yang termasuk non kayu antara lain damar, rotan, bamboo, madu, dan lainlain.

Berdasarkan kemampuan untuk dipasarkan, manfaat hutan juga dapat dibedakan menjadi dua yaitu : manfaat marketable dan manfaat non marketable. Manfaat hutan non marketable adalah barang dan jasa hutan yang belum dikenal nilainya atau belum ada pasarnya, seperti : beberapa jenis kayu local, kayu energy binatang, dan seluruh manfaat intangible hutan (Siti Latifah, 2004).

Mamosol terdiri atas 10 Penggunaan langsung yaitu nilai penggunaan langsung kayu bangunan rumah, nilai penggunaan langsung kayu bakar, nilai penggunaan hewan berburu, nilai penggunaan langsung damar. Nilai penggunaan langsung rotan, nilai penggunaan langsung bambu, nilai penggunaan langsung burung, nilai penggunaan langsung sayuran, nilai penggunaan langsung obat-obatan, dan nilai penggunaan langsung buah-buahan.

Tabel 1. Nilai Produksi Hasil Hutan di Hulu DAS Wae Ruapa Desa Rambatu

\begin{tabular}{|c|c|c|c|c|}
\hline Nilai Guna & $\begin{array}{l}\text { Jumlah } \\
\text { produksi } \\
(\mathrm{kg} / \mathrm{bln})\end{array}$ & $\begin{array}{l}\text { Harga } \\
(\mathrm{Rp})\end{array}$ & $\begin{array}{c}\text { Jumlah } \\
\text { bulan }\end{array}$ & $\begin{array}{l}\text { Nilai Produksi / } \\
\text { tahun ( Rp ) }\end{array}$ \\
\hline Kayu Bangunan & $720 \mathrm{~m}^{3}$ & 1.500 .000 & 12 & 1.080 .000 .000 \\
\hline Kayu Bakar & $1.680 \mathrm{Ikat} / \mathrm{bln}$ & 6.000 & 12 & 10.080 .000 \\
\hline \multicolumn{5}{|l|}{ Hewan Berburu } \\
\hline a. Babi & $105 \mathrm{~kg} / \mathrm{bln}$ & 25.000 & 12 & 31.500 .000 \\
\hline b. Rusa & $90 \mathrm{~kg} / \mathrm{bln}$ & 25.000 & 12 & 27.000 .000 \\
\hline $\begin{array}{l}\text { Rotan (Daemonorobs } \\
\text { rubra) }\end{array}$ & 15 btng/bln & 3.000 & 12 & 540.000 \\
\hline Damar (Shorea sp) & $3000 \mathrm{~kg} / \mathrm{bln}$ & 15.000 & 12 & 10.800 .000 \\
\hline Bambu & $15 \mathrm{btng} / \mathrm{bln}$ & 10.000 & 12 & 1.800 .000 \\
\hline Burung & - & - & - & - \\
\hline
\end{tabular}

DOI: $10.30598 /$ jhppk.2020.4.2.216

ISSN ONLINE: 2621-8798 


\begin{tabular}{lcccc}
\hline $\begin{array}{l}\text { Sayur sayuran } \\
\text { a. Ganemu }\end{array}$ & 150 ikat/bln & 5.000 & 12 & 9.000 .000 \\
b. Labu siam & $350 \mathrm{bh} / \mathrm{bln}$ & 1.000 & 12 & 4.200 .000 \\
\hline & & & & \\
$\begin{array}{l}\text { Obat obatan } \\
\text { a. Madu }\end{array}$ & $40 \mathrm{btl} / \mathrm{thn}$ & 50.000 & 1 & 2.000 .000 \\
& & & & \\
Buah buahan & $32.000 \mathrm{bh} / \mathrm{thn}$ & 8.000 & 1 & 256.000 .000 \\
a. Durian & $43.000 \mathrm{bh} / \mathrm{thn}$ & 1.000 & 1 & 43.000 .000 \\
b. Salak & $45.000 \mathrm{bh} / \mathrm{thn}$ & 2.000 & 1 & 90.000 .000 \\
c. Manggis & $20.000 \mathrm{bh} / \mathrm{thn}$ & 3.000 & 1 & 60.000 .000 \\
d. Cempedak & $10.000 \mathrm{bh} / \mathrm{thn}$ & 2.000 & 1 & 20.000 .000 \\
e. Langsat & \multicolumn{4}{c}{ Total } \\
\hline
\end{tabular}

Sumber : olah data primer, 2019

Jumlah produksi kayu bangunan rumah yang di pakai oleh masyarakat desa Rambatu yaitu $720 \mathrm{~m}^{3} /$ bulan dengan harga jual $\quad 1.500 .000 / \mathrm{m} 3$. Total nilai produksi/tahunnya dari kayu pembangunan rumah sebesar Rp. 1.080.000.000,-. Kayu bakar yaitu $1.680 \mathrm{ikat} / \mathrm{bulan}$ dengan harga jual pasar Rp. 6.000,- / ikat total nilai produksi kayu bakar dalam 1 tahun $\mathrm{Rp}$. 10.080.000,- Manfaat lainnya dapat dilihat dalam Tabel 2 berikut.

Hasil perhitungan penggunaan langsung ekosistem menggunakan total nilai penggunaan langsung dapat dikualifikasi dalam Tabel 2.

Tabel 2. Kuantifikasi Nilai Penggunaan Langsung Ekosistem Hutan di Desa Rambatu

\begin{tabular}{clcc}
\hline No & \multicolumn{1}{c}{ Jenis Penggunaan Langsung } & $\begin{array}{c}\text { Nilai Penggunaan } \\
(\mathrm{Rp} / \mathrm{Thn})\end{array}$ & Presentase $(\%)$ \\
\hline 1 & Kayu Bangunan Rumah & 1.080 .000 .000 & 65,41 \\
2 & Kayu Bakar & 10.080 .000 & 0,61 \\
3 & Hewan Berburu & 58.500 .000 & 3,54 \\
4 & Rotan & 540.000 & 0,03 \\
5 & Damar & 18.000 .000 & 1,09 \\
6 & Bambu & 1.800 .000 & 0,11 \\
7 & Burung & - & 0,00 \\
8 & Sayuran & 13.2000 .000 & 0,80 \\
9 & Obat-obatan & - & 0,00 \\
10 & Buah-buahan & 469.000 .000 & 28,40 \\
\hline
\end{tabular}

Tabel 2 menunjukkan bahwa kuantifikasi nilai penggunaan langsung dari Desa Rambatu Kecamatan Inamosol memiliki total penggunaan langsung ekosistem hutan oleh masyarakat Desa Rambatu Kecamatan Inamosol adalah Rp. 1.651.120.000,- /Tahun.

\section{Nilai Penggunaan Tidak Langsung}

(Indirect Use Value).

Perhitungan nilai penggunaan tidak langsung ini didekati dengan metode benefit transfer. Metode benetif transfer merupakan metode pendekatan pemindahan asas manfaat 
yang digunakan untuk memperkirakan suatu keadaan pada suatu kondisi yang serupa. Dalam hal ini diasumsikan bahwa hutan disekitar Hulu DAS Wae Riuapa, apabila mengalami kerusakan akibat erosi maka akan menimbulkan nilai kerugian yang serupa. Hasil perhitungan ini kemudian dilakukan berdasarkan luasan hutan sehingga didapatkan nilai dari fungsi atau guna dari hutan sebagai penahan erosi.

\section{Nilai pilihan (Option Value )}

Nilai pilihan untuk hutan diestimasi dengan menggunakan metode benefit transfer, yaitu metode pedekatan pemindaan asas maanfaat dari tempat lain ( dimana sumberdaya tersedia ) benefit tersebut di transfer untuk memperoleh perkiraan yang kasar mengenai maanfaat dari lingkungan.. Nilai total dari manfaat flora dan fauna di dapatkan dengan cara mengkonversi nilai ketetapan ke rupiah kemudian di kalikan dengan luasan hutan. Nilai Pilihan merupakan nilai harapan masa yang akan datang terhadap komoditas yang saat ini digunakan maupun yang belum di manfaatkan. Nilai Pilihan ini meliputi jenis flora dan fauna. Ekosistem Hutan yang ada pada lokasi penelitian yang tumbuh secara alami memiliki potebsi sumberdaya alam, flora dan fauna yang cukup banyak.

Berdasarkan hasil wawancara dengan responden yang berada di sekitar Hulu DAS

\section{Nilai Ekonomi Total ( Total Economic Value ).}

Nilai Ekonomi Total ekosistem hutan yang terdapat di desa Rambatu kecamatan Inamosol, sesuai hasil idenfikasi seluruh manfaat hutan yang di dapatkan di Hulu DAS
Panjang DAS Wae Riuapa $331 \mathrm{~km}$ mulai dari desa rambatu kec.inamosol (Hulu DAS) sampai dengan desa waimital dan kairatu kec. kairatu. Sehingga apabila kegiatan pembuatan talut dilakukan di sepanjang aliran sungai,dengan daya tahan 10 tahun di butuhkan biaya Rp 13.856.267,34. Maka besarnya Total nilai penggunaan tidak langsung pada pembuatan talut di sekitar aliran sungai sebesar Rp. 58.642.448,954

Wae Riupa, cukup banyak jenis flora dan fauna. Namun selama ini belum dimanfaatkan secara optimal.Selama ini, jenis flora dan fauna yang di ambil hanya untuk kebutuhan sendiri. Perhitungan nilai pilihan berdasarkan metode nilai tukar relatif, yaitu hanya jenis flora dan fauna di nilai sama dengan harga barang yang ada di pasar. Nilia tukar dolar AS terhadap Rupiah dengan nilai jual sebesar Rp 14.212,00 sedangkan nilai beli Rp 14.070,00 sehingga rata - rata nilai tukar dolar terhadap rupiah adalah $\mathrm{Rp}$ 14.141,00. Nilai pilihan hutan di Hulu DAS Wae Riupa desa Rambatu kec. Inamosol berdasarkan kurs Rupiah terhadap Dolar adalah sebesar Rp 212.155,- per tahun, dikali dengan luas hutan di Hulu DAS Wae Riuapa yang berdasarkan citra landsat sebesar 53.661,95 ha. Maka nilai pilihan hutan di Hulu DAS Wae Riupa adalah sebesar Rp 11.384.651.002,25.

Wae Riupa secara keseluruhan nilai manfaatnya dapat diketahui setelah menjumlahkan hasil dari penilaian terhadapmanfaat hutan secara keseluruan. Hasil selengkapnya dapat dilihat pada table 
Tabel .3. Nilai Total Ekonomi Hutan pada Hulu DAS Wae Riuapa

\begin{tabular}{lcc}
\hline \multicolumn{1}{c}{ Kategori Manfaat } & Nilai Manfaat Ekonomi Rp/Tahun & Presentase \% \\
\hline Manfaat Langsung & 1.651 .120 .000 & 12 \\
Manfaa tidak langsung & 458.642 .448 .954 & 3 \\
Manfaat Pilihan & $11.384 .651 .002,25$ & 84 \\
\hline Total & $13.494 .413 .451,204$ & 100 \\
\hline
\end{tabular}

Sumber : Data Primer, 2019

Berdasarkan Tabel 3, memperlihatkan bahwa nilai penggunaan langsung ekosistem hutan di hulu DAS Desa Rambatu kecamatan Inamosol memiliki peranan yang sangat penting. Hal ini sesuai dengan hasil wawancara dengan responden bahwa keberadaan ekosistem hutan yang terdapat di sekitar perkapungan mereka memberikan dampak positif terhadap kehidupan mereka.

\section{KESIMPULAN}

- Hasil perhitungan nilai penggunaan langsung (Direct Use Value), nilai penggunaan tidak langsung (indirect use value) sebesar Rp. 1.645.920.00,-, nilai pilihan (option value) sebesar Rp. 458.642.449,-, manfaat pilihan sebesar Rp. 11.384.651.002, dan nilai ekonomi total (Total Economy Value TEV) sebesar 13.489.213.451,-.

- Potensi hasil hutan yang dimanfaatkan dan dikelola oleh masyarakat di Desa Rambatu. Jenis-jenis hasil hutan kayu bernilai ekonomi tinggi seperti kayu besi, kayu gofasa, kayu makila, kayu meranti, dan jenis kayu bangunan lainnya yang sejauh ini menjadi incaran di pasaran lokal sampai pasar nasional.

\section{DAFTAR PUSTAKA}

Bahruni, Suhendang,E., Darusman,D., Alikodra,H.d., 2007. Pendekatan Sistem Dalam Pendugaan Nilai Ekonomi Total Ekosistem Hutan : Nilai Guna Hasil Hutan Kayu dan Non Kayu. Jurnal Penelitian Sosial dan Ekonomi
Salah satu dampak positif yang mereka rasakan secara langsung adalah persediaan sayuran dan tanaman obat-obatan yang melimpah didalam hutan serta hewan buruan seperti babi yang berkembangbiakkannya sangatt banyak,bahkan suda menjadi hama pengganggu bagi tanaman pertanian dan perkebunan.

- Hasil hutan bukan kayu seperti satwa buruan terutama jenis-jenis burung burung endemik dan bernilai ekonomi seperti nuri, kakatua seram, gosong Maluku, Pombo hutan, dan lainnya.

- Hasil hutan bukan kayu seperti getah damar, madu, rotan, bambu dan lainnya juga terus mengalami permintaan pasar yang tinggi, diikuti dengan tanaman hortikultura dan tanaman perkebunan seperti cengkih, pala, kakao, kelapa, buah-buahan seperti salak, durian, cempedak, manggustang, duku, langsat, dan lainnya.

Kehutanan. Volume 4 No. 3 September 2007, Halaman 369-378. Institut Pertanian Bogor.

Bishop,J.T., 1999. Valuing Forest : A Review of Methods and Application in Developing Countries. London : 
International Institute for Environment and Development.

Fakultas Kehutanan IPB, 1999. Kajian Sistem Nilai Hutan Produksi. Bogor : Fakultas Kehutanan IPB.

Hasibuan,B. 2014. Valuasi Ekonomi lingkungan Nilai gunaan Langsung dan Tidak langsung komobitas ekonomi. Jurnal Signifikan Volume 3 Nomor 2 Oktober 2014. Universitas Sahid Jakarta.

Indriyanto, 2006. Ekologi Hutan Jakarta: Penerbit PT Bumi Aksara Mempertahankan Fungsi Hidrologis Daerah Aliran Sungai ( DAS), Prosiding Lokakarya Dampak Hidrologis Hutan, Agroforestri, dan Pertanian Lahan Kering sebagai Dasar Pemberian kepada Penghasil Jasa Lingkungan di Indonesia, ICRAF, Padang, Sumatera Barat, 23-38.

Jefri Leo, 2014. Penentuan Komoditas Unggulan Pertanian dengan Metode Analitycal Hierarchy Process (AHP). Jurnal Saintia Matematika, Volume 02 (3). (2014), ISSN : 2337-9197.

Latifah,S., 2004. Penilaian Ekonomi Hasil Hutan Non Kayu.

Pearce dan D. Moran 1994. The economic value of biodiversity.Earthcan, London, UK. 172 pages. ISBN 1-85383-195-6. Price 12. 95 (paperback).
Rakhal,S. dan Surry,Y., 1999. Economic Value of Big Game Hunting : The Case of Moose Hunting in Ontario. Journal of forest economics 4 (1) : 29-60.

Suprayitno,A.R., Sumardjo,S. dan Gani,D.S. 2011. Model peningkatan partisipasi petani sekitar hutan dalam pengelolaan hutan kemiri rakyat: studi kasus pengelolaan hutan kemiri kawasan pegunungan. Jurnal Penelitian Sosial dan Ekonomi Kehutanan. Volume 8 No.3 September 2011. Hal.176-195.

Wahanisa,R., 2015. Model Pengelolaan Hutan bersama Masyarakat (PHBM). Yustisia Jurnal Hukum. Universitas Negeri Ssebelas Maret. Surabaya.

Widada, 2004. Nilai Manfaat Ekonomi dan Pemanfaatan Taman Nasional Gunung Halimun bagi masyarakat. [Disertasi\} Sekolah Pascasarjana IPB, Bogor.

Wulandari, 2007. Penanganan Sedimentasi Waduk Mrica.Berkala ilmiah Teknik Keairan.Vol 13 (4) Desember 2007,264-271

Zoebisch, dkk 2005, Integrated Watershed Management (studi and Experiences from Asia), Asian Intitute of Technology, Pathumthani, Thailand. 